\title{
Communicating needs for robots in a developing economy and national development : a case of Nigeria
}

Communiquer les besoins en robots dans une économie en développement et le développement national : un cas du Nigéria

Vermittlung des bedarfs an robotern in einer sich entwickelnden wirtschaft und nationalen entwicklung : ein fall von Nigeria

\section{Ifeyinwa Nsude}

\section{(2) OpenEdition}

\section{Journals}

Electronic version

URL: http://journals.openedition.org/ctd/2578

DOI: $10.4000 /$ ctd. 2578

ISSN: 2491-1437

\section{Publisher}

Chaire Unesco Pratiques émergentes en technologies et communication pour le développement

Printed version

ISBN: 2491-1437

Electronic reference

Ifeyinwa Nsude, "Communicating needs for robots in a developing economy and national

development : a case of Nigeria", Communication, technologies et développement [Online], 8 | 2020,

Online since 30 June 2020, connection on 28 March 2021. URL: http://journals.openedition.org/ctd/ 2578 ; DOI: https://doi.org/10.4000/ctd.2578

This text was automatically generated on 28 March 2021.

Communication, technologies et développement 


\section{Communicating needs for robots in a developing economy and national development : a case of Nigeria}

Communiquer les besoins en robots dans une économie en développement et le développement national : un cas du Nigéria Vermittlung des bedarfs an robotern in einer sich entwickelnden wirtschaft und nationalen entwicklung : ein fall von Nigeria

Ifeyinwa Nsude

\section{Introduction}

Historically, the word robot was first brought forward by Carpek, (1921) in his play 'Rossum's Universal Robots' (RUR). Later Deval \& Ergelberger as cited in (Fabiyi, Abdulmalik \& Falade, 2016) developed the first industrial modern robots in the late 50s and early 60 's. Robot is a machine that is human-like and programmed to reason and respond quickly than human counterpart using knowledge base inference engine (Mamudu \& Mustapha, 2013 as cited in Martin, 2015). Furthermore, the two scholars posit that a robot is reprogrammable, multifunctional manipulator designed to move materials, parts, tools or specialized devices through variable programmed motions for the performance of a variety of tasks.

In view of rapid advances in technology, there is a surge of public interest in automation and robotics (International Federation of Robotics, IFR, 2017). It has been estimated by IFR that over 25 million industrial robots will be at work in 2019 thereby representing an average annual rate of 12\% between 2016 and 2019 (IFR, 2016). Therefore, the anticipated industrial revolution no doubt has led to debates by many scholars and researchers who argue for and against the use of robots particularly in the areas of productivity and employment (IFR, 2015). 
The researcher looked at the two sides of the debate with the intention of initiating a discussion on whether deployment of robots can facilitate economic growth and national development in Nigeria or cause unemployment. Also this paper focused on the premise that any invention or innovation not reported will not be known. Hence, the importance of creating awareness on the need for deployment of robots in Nigeria.

In this paper, robotics which is an area of Artificial Intelligence (AI) deals with the use of robots and has to do with the principles and science of robots is used interchangeably with the word robots.

\section{Objectives}

- To determine whether robots can contribute to economic and national development.

- To investigate whether the deployment of robots will lead to unemployment.

- To create awareness on the need for the deployment of robots in Nigerian in preparation for the anticipated Industrial Revolution.

\section{Method}

5 This is a position paper that employed qualitative approach which discussed in details the need for deploying robots in a developing economy such as Nigeria.

\section{Theoretical Framework}

6 This work is anchored on Technological Determinism Theory and Social Construction of Technology Theory (SCOT). The term technological determinism theory originated from ThorsteinVeblem (1857 - 1929), an American Sociologist and Economists. The first major elaboration of a technological determinist view of socio economic development came from the German Philosopher and Economist, Karl Marx. He believed that technological progress leads to newer ways of production in a society and this ultimately influences the cultural, political and economic aspects of a society, thereby inevitably changing society itself.

7 The theory was further developed by Marshal McLuhan in 1964 (Asemah, Nwammuo \& Nkwam-Uwaoma, 2017). Technological determinism is a reductionist theory that presumes that a society's technology drives the development of its social structure and cultural values.Thus, technological determinism has been summarized as the belief in technology as a key governing force in the society. (Asemah, Nwammuo \& Nkwam Uwaoma, 2017).

8 However, Social Construction of Technology Theory (SCOT) which is a theory within the field of science and technology studies argues that technology does not determine human action, rather human action shapes technology. This could of course raise an argument for debate. The theory further argues that the ways a technology is used cannot be understood without understanding how that technology is embedded in its social context. SCOT is therefore a response to technological determinism.

SCOT which was postulated by Mackenzie and Wajcman (1986) is not only a theory, but also a methodology which formalizes the steps and principles to follow when one wants to analyze the cause of technological failures or successes. The justification of the two 
theories in this study is that when awareness is created among Nigerians to see the need for the deployment of robots, it will be easier for them to accept the new technology. The new technology if accepted will impact positively into the cultural, social and economic sectors thereby facilitating Economic Growth and National Development.

\section{Literature Review}

The International Federation of Robots, IFR (2017), opines that robots improve productivity when they are applied to tasks that they perform more efficiently and to a higher and more consistent level of quality than humans. Also, Graetz and Michaels (2017) in their study of robotics concluded that robot densification increased annual growth of GDP and labour productivity between 1993 and 2007 by about 0.37 and 0.36 percentage points respectively across 17 countries studied. In a survey of 238 citi group clients, $70 \%$ believed that automation would encourage companies to move their manufacturing close to home and consolidate production (Citi \& Oxford Martin School, 2016).

11 Also, the Reshoring Initiative in the US estimates that 250, 000 jobs have been brought back to the country by reshoring and inward - bound foreign direct investment since 2010 (Reshoring Initiative, 2015). Furthermore, David Autoran economist at the Massa Chusetts Institute of Technology, in his work found out that automating a particular task so that it can be done more quickly or cheaply increases the demand for human workers to do the other tasks around it that have not been automated. He further argues that when automation or computerization makes some steps in a work process more reliable, cheaper or faster, this increases the value of the remaining human links in the production chain (IFR, 2015). On his own part, Besson (n.d. as cited in IFR, 2015) states that deployment of robots will create new jobs, citing the example of ATM which created new jobs.

In another study, Gordon (2006) posits that robots can help access new resources for instance, under the seas or under lakes (e.g. under water logging robot). Also, they can conduct mining in dangerous environments. Furthermore, Muro and Andes (n.d as cited in IFR, 2017) posit that Brookings Institution analysts report that countries that invested more in robots lost fewer manufacturing jobs than those that did not.

IFR (2017) sums it up with the statement that 'Automation does indeed substitute for labour as it is typically intended to do. However, automation also complements labor, raises output in ways that lead to a higher demand for labor, and interacts with adjustments in labour supply. He further added that even expert commentators tend to overstate the machine substitution for human labour and ignore the strong complementariness between automation and labour that increase productivity, raise earnings and augment demand for labour (IFR, 2017).

Frey and Osborn (2013) raised an interesting point in their summary that automation, and more specifically robots have a positive impact on employment. However, the two scholars added that the picture varies across different sectors, job types and skill level. of particular concern in public debate has been the fear that certain jobs will be wiped out entirely as a result of automation. 
15 Mamudu and Mustapha (2017) in their study opine that robots are actually creating new, high-paying jobs that require skill acquisition and replacing low skill workers. Citing a typical example in manufacturing, robot can perform mental tasks such as raw materials sorting, transporting and stocking, while higher - skilled play roles such as quality - related tasks which humans are more suitable for can be completed by higher skilled workers. The International Federation of Robotics (IFR, 2017) posits that robot increases productivity and competitiveness, thereby leading to increased demand and creation of new job opportunities.

16 In their study on 'A Role for Robotics in sustainable Development, Bugmam and Burein (2011) posit that Robots can help recycling resources, help reduce waste during industrial, agricultural production and could enable production methods that process less polluting by products. The two scholars also said that robots can help increase the yield in food production. For instance, use of a milking robot, for instance, DeLaval Milking robot increases the number of litres per day that a cow produces, because the cow can access the robot at any time. The main thing here is the voluntary nature of the milking. Bugmam and Burein (2011) further opine that in a country with low wages, it may be possible to only use the lessons learnt from robots. For example, a continuous milking service increases the yield. Still in the agricultural sector, robot could help monitor soil conditions, the health of plants and animals and adapt actions to very local conditions even plant by plant (Blackmore, 2009). Furthermore, deploying robots helps to upgrade firms that initially have lower productivity to avoid being driven out of the market through import competition (United Nations Conference on Trade and Development (UNCTAD, 2016).

17 UNCTA (2016) cited China as an example of a country that embarked on a government backed robot - driven industrial strategy entitled 'made in China 2015. China according to the report has brought more industrial robots than any other country in each year since 2013 and is likely to overtake Japan as the world's biggest operator of industrial robots.

18 Various studies show a positive correlation between automation and jobs. For example, a 2016 discussion paper for the centre for European Economic Research found that 'Overall, labour demand increased by 11.6 million jobs due to computerization between 1999 and 2010 in the EU 27 thus suggesting that job - creating effect Routine - Reducing Technological Change overcompensated the job destructing effect (Zierahn, Greery \& Arntz, as cited in IFR, 2017). Additionally, a review of the economic impact of industrial robots across 17 countries shows that robots increased wages whilst having no significant effect on total hours worked Graetz \& Michaels (2015 as cited in IFR, 2017).

19 Furthermore, Deloitte (2017) argue that while technology has potentially contributed to the loss of over 800,000 lower -skilled jobs (in the UK), there is equally strong evidence to suggest that it has helped to create nearly 3.5 million new higher skilled ones in their place (Deloitte in IFR, 2017). He further stated that countries with the highest robot density, notably German, and Korea have among the lowest unemployment rates.

20 Also, the major benefits to be gained from initiatives that explore technology applicable to developing communities is the empowerment of members of such communities, which could be intellectual skill acquisition or economic growth. It will also reduce the gap between urban and rural communities. 

This is because they are capable of doing dangerous and nasty tasks especially in the auto, nuclear and medical manufacturing industries. Robots unlike humans can carry out tasks with high degree of accuracy in environments which are subjected to extremely high or low temperature. Full of radiation, toxic substances and chemicals (Kabiyi, Abdulmalik \& Tiamiu, 2015 as cited in Fabiyi, Abdulmalik \& Falade, 2016). So far, many scholars in their studies posit that robots contribute to the growth of any economy if certain precautions are taken.

However, some scholars see and present robots as job killers. This is why some scholars and researchers still criticize the idea of using robots to develop our economy. To such ones using robots to increase productivity and create jobs is like taking one step forward and two steps backward.

Also, these countries whose major challenge is to create jobs for large number of lowskilled entrants to the labour force - such as in many parts of Africa - deploying robots under current cost structures may drive production costs up, rather than down (The third world Resurgence ,2017).

\section{Types of Robots}

- Drones : Drones, according to Fabiyi, Abdulmalik and Falede (2016) are robots with a flying capability which can be flown anywhere without the support of a pilot. These drones are therefore referred to as auto-pilot or Unmanned Arial Vehicle (UAV). Furthermore, the three scholars explained that drones can be equipped with other components such as machine guns and cameras to take pictures and record videos. Drones can be controlled either remotely by human operator or by a board computer and can be used to launch or prevent attack. Drones are applied in different sectors of economy such as agriculture, transport, infrastructure, entertainment and telecommunications (Kitonsa \& Kruglikov, 2018). The two scholars further posit that the problems which face developing countries such as sub-Saharan African which include famine, epidemic diseases, poverty among others can be addressed with the help of drone technology. Drone technology can be used in agricultural sector in the following ways - surveying farm fields ensuring product delivery and to spray insecticides, (Tripicchio, Satler, Dabisias, Ruffaldi, \& Avizzan 2015; Krishna, 2016; Bamburry, 2015, as cited in Kitonsa \& Krudlikov, 2018). On his own part (King, 2017 as cited in Kitonsa \& Krudlikov, 2018) posits that the pesticides are delivered at the rights spot and the right quantity. This means reduction in pesticides used, reduction in collateral damage to wild life and enhance cost efficiency.

- Driverless cars : These are self-driving cars also known as car-like robots. Fabiyi, Abulmalik and Falade, (2016) opine that the history of driverless cars can be dated back to 1478 when Leonardo da Vinci designed a first prototype. Driverless car according to the three scholars was legalized on US public road in 2011. Throwing more light on the benefits of driverless cars some scholars are of the view that they will reduce number of accidents, enhance traffic flow, improve emission compliance and commuters can sleep, read, make called while travelling (Anon, 2016).

- Exoskeletons : These are types of robots designed to assist individuals suffering from limb pathology to limb exoskeletons designed to augment normal, intact, limb function (Herr, 2009). 


\section{Classifications of exoskeletons}

- Shoes and exoskeletons that act in series with the human lower limb. Examples are the sprinbuck shoe, the power skip exoskeleton (http://www.powerskip.de), and the spring walker exoskeleton.

- Exoskeletons that act in parallel with the human lower limb for load transfer to the ground. Examples are Yagn's running aid, MITs hopping exoskeleton, and Kazerooni's load-carrying exoskeleton.

- Exoskeleton that acts in parallel with human joint(s) for forgue and work augmentations. Examples are the HAL 5 exoskeleton.

- Exoskeleton that act in parallel with a human limb for endurance augmentation. An example is the MIT climbing exoskeleton (Herr, 2009).

\section{Agricultural robot for field operations}

Agriculture has been the economic main stay of many nations that is why frantic efforts are made by both developed and developing nations to boost food production. Such efforts include mechanization of agriculture and quite recently the application of robots. Corroborating this point, Avital and Clement, (2016) posit that extensive research has been conducted on the application of robots and automation to a variety of field operations, and technical feasibility has been widely demonstrated. Also, Nof and Zhang (2009 as cited in Avital and Clement, 2016) posit that Agricultural productivity has increased significantly over years as a result of intensification mechanization and automation. Furthermore, recent studies indicate that the practice of robots or autonomous tractors in various agricultural tasks reduce the fuel consumption and air pollution (Gonzalez-de-soto, Emmi, Benavicles, Garcia, \& Gonzalez-de-santus, 2016; Gonzale-de-Santo 2015 as cited in Avital and Clement, 2016). In addition, automation has considerably increased the productivity of agricultural machinery by increasing efficiency, reliability and precision and reducing the need for human intervention (Schueller as cited in Avital \& Clement, 2016). To buttress this point, robotics and automation require a more costly specialized work force and equipment, they contribute to increased agricultural productivity because the required workforce, including skilled machine operators, generally declines enough to compensate for the higher initial cost (Avital \& Clement, 2016).

For agricultural applications for automation robotics require advanced technologies to deal with complex and highly variable environments and produce (Hiremath, Van der Heijden, Van Evert, Stain \& Ter-Braak, 2014 ; Nof, 2009 as cited in Avital \& Clement, 2016).

To boost agriculture (Canning, Edwards \& Anderson, (2004 as cited in Avital \& Clement, 2016) state that agricultural environments require that robot be capable of movement, unlike most robots in factories or vehicles in car parks. In addition, agricultural robots require the development of advanced technologies to deal with complex and highly variable environments and produce Nof, (2009). In Avital \& Clement, (2016).

On their own part Tervo \& Koivo, (2014 as cited in Avital and Clement, 2016), posit that human capabilities of perception, thinking and action are still unmatched in environments with anomalies and unforeseen events. As a result, human and robot 
skills are still complementary (Rodriguez \& Weisbin, 2003 as cited in Avital \& Clement, 2016).

\section{Medical and Health Care Robots}

Health care is an area of great concern to virtually all nations and as such should receive great attention. Medicine developed from traditional medicine to orthodox medicine which is now being facilitated by medical and health care robots.

These robots are designed for entirely different environments and tasks. Those that involve direct interactions with human users in the surgical theater, the rehabilitation centre and the family room (Allison, Maja \& Henrik, 2016). The three scholars described application areas, societal drivers, motivating scenarios, desired system capabilities and fundamental research areas that should be considered in the design of medical and healthcare robots.

Medicine and surgery have been slow to adopt computer assisted devices because there is a significant difference between industrial applications and human care. Also, surgeons have long been proud of a tradition of individual and direct patient interaction (Allison, Maja \& Henrik, 2010).

However, medical robots are not expected to replace the technical work of surgeons but to help them perform difficult tasks more accurately and repetitive tasks more precisely (Allison, Maja \& Henrik, 2016).

The three scholars further posit that if the right information is available, many medical procedures can be planned ahead of time and executed in a reasonably predictable manner, with the human exercising mainly supervisory control over the robot. Examples include preparation of bone for joint reconstruction in orthopedic surgery and placement of needles into targets in interventional radiology.

Reporting their experiences in a large community, hospital (Pie, Andrea, Marta, Fabio, Simone, Tomasso \& Guiseppe, 2018) posit that robotic surgery is feasible in a clinical setting. Its daily use is safe and easily managed, and it expands their application of minimally invasive surgery but cost benefit ratio must be evaluated.

\section{Artificial Assistants}

These are robots that are creative and innovative. They think independently, make complicated decisions, learn from mistakes and adapt quickly to changes in their surroundings. (Rainer \& Volker, n.d). The two scholars further stated that the two new kinds of robots which have appeared in the market in recent years which are artificial assistants are service robots and personal robots. They deliver various services for the benefit of humans and equipment.

Bischoff \& Graefe (n,d) opine that most service robots are special purpose machines with dedicated under carriages and manipulation (or process) devices.

Each one of them is a specialist, able to deliver only one kind of service in one kind of environment. If the deficiencies are overcome according to the scholars, it is hoped that service robots will eventually be economically as important as industrial robots. 
Furthermore, Bischoff \& Graefe (n,d) posit that the term "personal robot" has so far not been precisely defined by any robotic organization or institution (as with industrial manipulators and service robots). However, the term "personal robot" is often used in the context of robotic assistants or servants which either assist a human in doing some task or can do almost anything a user requires. This implies that personal robot is more advanced in terms of autonomy, versatility, interaction and communication abilities. The scholars explain that personal robot also perform useful task for the benefit of human and equipment. It is not limited to a single task e.g. vacuum cleaning but it is more universally employable e.g. to fetch drinks, lay the table, wash the dishes or clean an apartment among other things.

\section{Challenges of Robots}

\section{Taxation}

In virtually all the countries globally, taxes paid both by industries, companies and employees contribute extensively to Internally Generated Revenue (IGR). The argument from many quarters is that if robots replace humans that the government will loose revenues from taxes completely. Such scholars advocate a robot tax. The IFR on her own part believes that a robot tax is unwarranted given to the proven impact of robotics on employment and wages. It would deter badly-needed investment in robots, undermining the competitiveness of companies and states. Her argument is that profits not the means of making them should be taxed (IFR, 2017).

\section{Energy consumption and production}

Dzioubinks \& Chipman (1999) posit that robot use electricity, and this form of energy constitutes $25 \%$ of the energy used by UK households. This is only $5 \%$ of the household energy use in India, and as much less in Africa. So, energy consumed by robots in their current form cannot be neglected.

\section{Metal Detectors}

38 Currently, metal detectors are too expensive to be used in developing countries (Bernardine Ayorkor \& Thrishannta, (n.d). Also, the three scholars posit that the metal detectors cannot distinguish between metal pinsin the landmines and other debris found in typical battlefields, so de-miners are forced to frequently and unnecessarily dig to cover harmless metallic objects. The negative effects according to the three scholars is that the demining operations are drastically slowed down and the deminers' attention will be adversely affected. On a good note, the University of Moratuwa has developed a novel metal detector based on very low frequency (VLF) transmission with additional capacity to classify different types of alloys.

\section{Limited Access}

There is yet another major challenge the three scholars pointed out which is limited access to necessary resources for technology implementations. Furthermore, they 
pointed out that some of the challenges faced when implementing technology-related initiatives in Ghana include the low literacy rate among the rural population and high cost of technology such as good network connectivity.

\section{Nigerian Government's Policy on Artificial Intelligence} has approved the establishment of a new agency for robotics and artificial intelligence (Alajemba \& James, 2018). On his own part, the minister of Science and Technology, Dr. Ogbonnaya Onu opines that the proposed agency has been given official nod by President Muhammad Buhari (Alajemba and James, 2018). The two scholars stated that Nigeria Government has had some limited exposure to using artificial intelligence and robotics. But robotics and artificial intelligence are majorly still not part of technology life in Nigeria.

Marking the 2018 World Telecommunication and Information Society Day with the theme 'Enabling the positive use of artificial intelligence for all' the minister of communication Mr. Adebayo Shittu said that the ministry was committed to focus on the potential of the artificial intelligence to achieve the Sustainable Development Goal (SDGs) in 2030, and improve the nation's economy. He further affirmed that the artificial intelligence is taking centre stage with a lot of positive impact on people's lives (Shittu, 2018).

In Nigeria, the urgent need to use technology in reshaping humanity was advocated. Comms Week, (2018) writes that Nations including Nigeria presently bank on technology, robotics and artificial intelligence to enhance young people's interest in digital literacy.

\section{Challenges of Artificial Intelligence in Nigeria}

There are three basic and identifiable challenges of artificial intelligence in Nigeria ; there include, social economic barriers, inadequate infrastructure and cultural barriers (Somto, 2018).

\section{Social Economic Barriers}

Most Nigerian are skeptical about complicated artificial intelligence related to science and algorithm. They believed that artificial intelligence can only be understood by technical people and as such totally lose interest.

\section{Inadequate Infrastructure}

This to a great extent affects the creation of innovative tools with artificial intelligence in Nigeria. Power, cost of internet, and lack of government political will limit the progress and usage of artificial intelligence in Nigeria.

\section{Cultural Barriers}

Two of the most cultural barriers that inhibit the development of artificial intelligence in Nigeria are language and religion. But the most prominent among them is religion. 
Some religious beliefs classify artificial intelligence technology as 'demonic'. However, some of these problems are being looked into, so we expect a brighter future in the area of artificial intelligence in Nigeria.

Deployment of Robots for Economic Growth and National Development in Nigeria. economic development challenge in Nigeria. Cattle control robot (intelligent system) can be used to track location of cattle to avoid cattle rusting which is one of the challenges in the North East of Nigeria. Robots can also be used for milking the cows thereby leading to high productivity.

- Security : In Nigeria today, there are a lot of security challenges which include insurgency, kidnapping, armed robbery, stealing among others. These challenges really affect economic growth and national development in Nigeria. So, flying surveillance drone which is a flying robot that relays data (video, image or audio) of area under its foot print can be deployed. It moves without noise, and in the direction the user wants. Also knight scope robots used in monitoring parking lots in shopping mall, airport, sea ports, markets, banks, industries etc. can be deployed.

- Position Tracker Robots : These are intelligent system used in the prevention of human kidnapping, human trafficking, snatching of vehicles and goods. Examples are Global system 
mobile network (GSM), Global positioning system (GPS) and Global positioning route system (GPRS).

- Radio Frequency Identification Tag (RFID): This is a micro robot used in shopping mallto control payment and services of goods that ordinary human wisdom cannot control.

- Medical Procedure: Health seems to be the most important sector because good health is wealth. It is regrettable that most health workers in Nigeria are not dedicated to their work and as such many Nigerians die as a result of the doctors and nurses avoidable mistakes such as over dose of drugs, mistakes in surgical operations, non-dedication of most nurses among others. So, we need robots like surgical assistant robots, robotic prescription dispensing system, telepresence etc. for economic development in Nigeria. This robot will complement the functions of medical professionals.

- Mining and Oil Sectors: Nigeria is blessed with abundant mineral resources such as coal, clay, gypsum, Kaolin, Limestone, lead, oil, zinc, salt, marble, iron ore, sand, gold, manganese etc. Naturally, each state got a fair share of the minerals. The Nigeria Extractive Industry and Transparency Initiative (NEITI, 2016) report suggests that there are 30 different kinds of solid minerals in Nigeria that are unexploited. The level of exploitation of the minerals is very low in relation to the extent of deposits in the country. Many have therefore resorted to primitive way of extracting the resources and that has led to loss of so many lives. So if automated load haul dump trucks, loading and unloading robots are deployed in the mining and oil sectors there will be increase in productivity and safety.

- Nigeria Extractive Industry and Transparency Initiative Reports (NEITI, 2016 as cited in I Nsude \& Emeokoro, 2017).

- Entertainment Robots: Robots can be deployed in the area of entertainment. The benefits of robots in this area cannot be overemphasized. A good example is the case of a 26 - years old Nigerian who is the highest paid robotics engineer in the world. According to Guardian, (M.guardianing, Sept, 18 218) Silas Adekunle has become the highest paid in the field of robotic engineering and the founder and CEO of Reach Robotics, a company developing the world's first gaming robots. Adekunle, according to the report, graduated with a first class degree and has four years' background in robotics. He received support from various organisations including London Venture Partners ( $\$ 10$ million) his robots are of high quality because of their ability to show emotion with subtly - calibrated movements, apple stores priced his four legged "battle-bots" at $\$ 300$ and has put them in nearly all of its stores in the United States and Britain. Other areas that robots can benefit Nigeria include education, home services (Baby Sitting, cleaning the environment), census - to determine the actual population of the country, reporting the war zones, industrial processes among others.

\section{Awareness Creation on the Needs for Robots in Nigeria.}

Globally, many scholars and researchers anticipate industrial revolution. That is why developed countries are preparing seriously now in order to embrace the new technology by imbibing robots and robotic activities. For Nigeria, which is one of the developing countries to survive the anticipated industrial revolution, there is need to key into the use of robots now and subsequently the design of different types of robots in future. It is often said that anything not known or not reported does not exist, thus, the importance of awareness creation. Awareness means letting the right people know 
the information or service that exists and is available. So, the object of information drive in this context is to create awareness on the need for deploying robots in Nigeria.

The awareness creation therefore will achieve the following:

- Knowing that deployment of robots can help revamp Nigeria's dwindling economy instead of causing unemployment.

- Challenges of deployment of robots and the way forward.

- Knowing the role or importance of communication in development.

5 The researcher used integrated communication approach to create awareness on the need for robots in Nigeria. This will enable Nigerians to be aware of the numerous benefits of robots and their challenges in developed countries. Knowledge of these challenges will enable Nigeria to cope easily.

So the communication strategies that will be used to create awareness include ; the mass media (newspapers, magazines, radio, television among others), indigenous media, interpersonal communication, hand bills, bill boards, social media, workshops, seminars, conferences and symposia.

- Mass media : The mass media are veritable conveyor belt of information to the people which use technology to reach their scattered audience simultaneously (Nsude, 2009). They include broadcast media (radio and television), print media (magazines, newspapers and books). Through their various programmes such as phone in programmes, discussions interviews, features, opinion columns, the mass media can create awareness on the need to deploy robots in Nigeria.

- Indigenous media : Meaningful development plans and programs in Africa, Nigeria inclusive should be designed such that they will have their greatest beneficial impact in rural areas providing for "neglected majority of rural Africans to improve their lives through their own efforts, Opubor (1985 as cited in Nwosu \& Nsude, 2017). Indigenous Media include ; town crier, market square, visits, church, village squares, metal gongs and wooden gongs. These media of communication if applied to the rural areas using local dialects will actually create awareness on the need for robots in Nigeria.

- Interpersonal communication : This includes face to face communication between two people, dyadic communication when a small group is involved and macro group communication can create meaningful awareness among Nigerians on the need for robotics in Nigeria.

- Hand bills, Bill boards and social media : Snappy and captivating messages on the need for robots can be placed on hand bills, bill boards and social media.

-Workshops, Seminars, Conferences and Symposia : These can also contribute to awareness creation on the need for robotics in Nigeria. Proceedings from such gathering are supposed to be published in both local, national and international journals and books. All these communication strategies should be clear, short, simple and persuasive in other to make great impact.

\section{Conclusion and Recommendations}

57 The reviewed literature revealed that there is great need for the deployment of robots in Nigeria because of their numerous benefits. Some of these benefits include, skills such as strength precision and sensing which surpass those of humans and could lead to high productivity, thereby facilitating Economic Growth and National Development. 
However, the challenges of the new technology were $\mathrm{x}$-rayed in this paper and the main challenge according to some scholars will be unemployment. The position of this paper is that new jobs will be created citing the case of ATM which created new jobs for bankers instead of leading to unemployment. Emphasis was laid on human-robot partnership for high efficiency because there are jobs that robots cannot do.

Areas where robots can be deployed in Nigeria include : agriculture, security, medical procedure, mining and oil sectors, entertainment, surveillance, among others. The paper was based on the premise that "invention or technology not reported does not exist" hence the importance of awareness creation among Nigeri ans on the need for the deployment of robots.

In order to reach Nigerians, the author adopted integrated communication approach which include : the Mass Media, Indigenous Media, Interpersonal Communication, Hand Bills and Bill boards, Workshops, Seminars, conferences, symposia and social media.

\section{As a result of this conclusion, the study suggest as follows ;}

- The government should establish Federal Agency for robots and robotics that will be situated in Abuja with branch offices in different zones of Nigeria. These zones will monitor the awareness creation among Nigerians by giving important information about robots and robotics using different communication strategies such as ; the mass media (newspapers, magazines, radio, television among others), indigenous media, interpersonal communication, hand bills, bill boards, social media, workshops, seminars, conferences and symposia. The commission will be expected to oversee the smooth running of robots' deployment, maintenance and subsequently design.

- The educational planners should incorporate robots and robotics into the curriculum and emphasis should be laid on creative and relevant educational programmes. So the educational system should be re-designed. Such programme should start early in the child's life so that students in our higher institutions can manufacture their own robots thereby contributing to economic growth. Emphasis should be laid on critical thinking among the students. Examples include how students in the University of Moratuwa were encouraged to develop a novel metal detector based on very low frequency (VLF) transmission with additional capacity to classify different types of alloys. Also, it is on record now that a 26year old Nigeria is the highest paid robotic engineer in the whole world presently. Recently some students in a local secondary school in Ebonyi State of Nigeria constructed surveillance drones because their physics teacher challenged them to think critically in line with the present day technological age. Government should also establish faculty of artificial intelligence (AI) at all levels of education.

- Every owner should pay tax to the government for the needed Internally Generated Revenue (IGR). Since productivity will be very high, there is need to create social amenities and universal basic income for all people regardless of job status (Fish, 2017), to make life comfortable for the masses particularly those who will be displaced by robots.

- There is need to enter industrialization or automation processes along traditional lines that is human-robot partnership at this teething stage in Nigeria, hence there is need for awareness creation on the need for robots and robotics. 


\section{BIBLIOGRAPHY}

Alajemba, N. \& James, C. (2018). Nigeria to Set up New Agency for Robotics and Artificial Intelligence. Available at www.itedgenews.ng, [Accessed Dec. 13, 2018].

Allison, M. O., \& Maja, J. M. (2010). Medical and Health-Care Robotics Achievements and Opportunities. IEE Robotics and Automation Magazine.

Allison, M. O., \& Maja, J. M. (2010). Medical and Health-Care Robotics Achievements and Opportunities. IEE Robotics and Automation Magazine.

Allison, M. O., Maja, J. M., \& Henrik, I. C. (2010). Medical and Health-Care Robotics Achievements and Opportunities. IEE Robotics and Automation Magazine.

Anon, (2016). Available at : http://whatis.techtarget.com , [Accessed Aug.18 2016].

Arntz, M., Terry G., \& Ulrich, Z. (2016). In International Federation of Robotics (2017). TheImpact of Robots on Productivity, Employment and Jobs. A Positioning Paper by the International Federation of Robotics.

Asemah, E. S., Nwammuo, A. N., \& Nkwam-Uwaoma, A. O. A. (2017). Theories and Models of Communication; Jos: MATKOL Press.

Autor, D. (2015). In International Federation of Robotics (2017). The Impact of Robots on Productivity, Employment and Jobs. A Positioning Paper by the International Federation of Robotics. Autor, D. (2015). In International Federation of Robotics (2017). The Impact of Robots on Productivity, Employment and Jobs. A Positioning Paperby the International Federation of Robotics. Autor, D. (2015). In Mamudu, F., \& Lamido, A. A. (2017). A Comparative Analysis of the Effects of Robots on Nigeria Economy. IOSR Journal of Computer Engineering, 19(5),36-40. www.iosrjournals.org

Avital, B., \& Clement,V. (2016). Agricultural Robots for Field Operations: Concepts and Components Journal homepage:www.elsevier.com/locate/ISSN/15375110. Published online $13^{\text {th }}$ July, 2016.

Avital, B. and Clement, V. (2016). Agricultural Robots for Field Operations: Concepts and Components, [online]. Available at: www.elsevier.com/locate/ISSN/15375110.[Accessed $13^{\text {th }}$ July, 2016].

Bernadine, D. M., \& Thrishatha, N. (No date). Robotics, Education and Sustainable Development. Bessen, J. (2015). In International Federation of Robotics (2017). The Impact of Robots on Productivity, Employment and Jobs. A Positioning Paper by the International Federation of Robotics. Blackmore, B. S. (2009). In Bugman, \& Burein (2011). A Role for Robotics in Sustainable Development. Proc. Of IEEE Africon 2011, 13 - 15 September. Livingstone, Zambia.

Bugman, G., Siegel, M., \& Burein, R. (2011). In Guido, B. (2011). A Role for Robotics in Sustainable Development. Proc. of IEEE Africon 2011, 13 - 15 September. Livingstone, Zambia.

Bugman, G., Siegel, M., \& Burein, R. (2011). In Guido, B. (2011). A Role for Robotics in Sustainable Development. Proc. of IEEE Africon 2011, 13 - 15 September. Livingstone, Zambia. 
Carning, J. R., Edwards, D. B., \&Anderson, M. (2004). In Avital, B., \& Clement, V. (2016). Agricultural Robots for Field Operations: Concepts and Components. Journal homepage: www.elsevier.com/locate/ISSN/15375110. Published online $13^{\text {th }}$ July, 2016.

Citi and Oxford Martin School (2016). In International Federation of Robotics (2017). The Impact of Robots on Productivity, Employment and Jobs. A Positioning Paper by the International Federation of Robotics.

Dzioubinnski, O., \& Chipman, R. (1999). In Guido, B., Mel, S., \& Rachel, B. (2011). A role for Robotics in Sustainable Development. Proc. of IEEE, Africon 2011, 13 - 15 September, Livingstone, Zambia.

Eric, F. (2017). Why the Rise of Robots will hit Developing Countries Hardest.

Fabiyi, S. D., Abdulamalik, A. O., \& Falade, A. J. (2016). Use of Robots as Facilitators of SocioEconomic Growth and National Development: A Review. International Journal of Electrical and Electronics Research, 4(3), 109 - 114.

Fabiyi, S. D., Abdulmalik, A. O., \& Tiamiu, H. A. (2016). In Fabiyi, S. D., Abdulamalik, A. O.,\& Falade, A. J. (2016). Use of Robots as Facilitators of Socio-Economic Growth and National Development: A Review. International Journal of Electrical and Electronics Research, 4(3), 109 - 114.

Frey, C., \& Osborne, M. (2013). In International Federation of Robotics (2017). The Impact of Robots on Productivity, Employment and Jobs. A Positioning Paper by the International Federation of Robotics.

Gonzalez-de-Soto M., Emmi, L., Benavides, C., Garcia, I., \& Gonzales-de-Santos, P. (2016). In Avital, B. and Clement, V. (2016). Agricultural Robots for Field Operations: Concepts and Components. Journal homepage:www.elsevier.com/locate/ISSN/15375110. Published online $13^{\text {th }}$ July, 2016.

Gordon, R. J. (2006). In Guido, B. (2011). A Role for Robotics in Sustainable Development. Proc. Of IEEE Africon 2011, 13 - 15 September. Livingstone, Zambia.

Graetz, G., \& Guy, M. (2015). In International Federation of Robotics (2017). The Impact of Robots on Productivity, Employment and Jobs. A Positioning Paper by the International Federation of Robotics.

Hiremath, V. H., Van Evert, F. K., Stein, A., \& TerBraak, C. J. F. (2014). In Avital, B. and Clement, V. (2016). Agricultural Robots for Field Operations: Concepts and Components. Journal homepage: www.elsevier.com/locate/ISSN/15375110. Published online $13^{\text {th }}$ July, 2016.

Hugh, H. (2009). Exoskeleton and Orthoses: Classification, Design, Challenges and Future Directions Journal of NeuroEngineering and Rehabilitation. http://www.jneuroengrehab.com/ content/6/1/21

International Federation of Robotics (2016). World Robotics Industrial Robots 2016.

International Federation of Robotics (2017). The Impact of Robots on Productivity, Employment and Jobs. A Positioning Paper by the International Federation of Robotics.

King, A. (2017). In Kitonsa, H., \& Kruglikov, S. V. (2018). Significance of Drone Technology for achievement of the United Nations Sustainable Development Goals. www.r-economy.ru

Kitonsa, K., \& Kruglikov, S. V. (2018). Significance of Drone Technology for achievement of the United Nations Sustainable Development Goals. www.r-economy.ru

kwawamoto, H., \& Sankai, Y. (2009). Exoskeleton and Orthoses: Classification, Design, Challenges and Future Directions Journal of NeuroEngineering and Rehabilitation. http://

www.jneuroengrehab.com/content/6/1/21 
Mackenzie, D., \& Wajcman, J. (1986). In Asemah, E. S., Nwammuo, A. N., \& Nkwam-Uwaoma, A. O. A. (2017). Theories and Models of Communication; Jos: MATKOL Press.

Mamudu, F., \& Lamido, A. A. (2017). A Comparative Analysis of the Effects of Robots on Nigeria Economy. In Martin, F. (2015). Rise of Robots. www.wired.com/brandlab/2015/04/rise-machinesfuture-lots-robots-jobs-humans/

McLuhan, M. (1964). In Asemah, E. S., Nwammuo, A. N., \& Nkwam-Uwaoma, A. O. A. (2017). Theories and Models of Communication; Jos: MATKOL Press.

Muro, M., \& Scott, A. (2015) In International Federation of Robotics (2017). The Impact of Robots on Productivity, Employment and Jobs. A Positioning Paper by the International Federation of Robotics. Nof, S. Y. (2009). In Avital, B., \& Clement, V. (2016). Agricultural Robots for Field Operations: Concepts and Components. Journal homepage :

www.elsevier.com/locate/ISSN/15375110. Published online $13^{\text {th }}$ July, 2016.

Nof, Z. (2013). In Avital, B., \& Clement, V. (2016). Agricultural Robots for Field Operations : Concepts and Components www.elsevier.com/locate/ISSN/15375110. Published online $13^{\text {th }}$ July, 2016.

Nsude, I. (2009), Human rights abuses in the Niger Delta: What can the media do? In: Wilson, D. (2009). Communication Approaches to peace Building in Nigeria. Akwa Ibom : BBM Resources Nig. Ltd. Opubor, A. E. (1985). In Nwosu, I., \& Nsude, I. (2017). Trado-Modern Communication Systems Interfaces and Dimensions; Enugu: Immaculate Publications Ltd.

Pier, C. G., M. D., Andrea, C., M. D., Marta, A. M. D., Fabio, S. M. D., Simone, C. M. D., Tommaso, B. M. D., \& Gluseppe, M. D. (2018). Robotics in General Surgery, Personal Experience in a Large Community Hospital. ARCH SURG, 138, www.archsurg.com, downloaded 2018.

Rainer, B., \& Vollce, G. (no date). Hermes - a Versatile Personal Robotic Assistant, Proceedings of the IEE, Human Interactive Robotics. Intelligent Robots Laboratory, Bundeswehr University, Munich, 85577 Neubiberg, Germany.

Restoring Initiative (2015). In International Federation of Robotics (2017). The Impact of Robots on Productivity, Employment and Jobs. A Positioning Paper by the International Federation of Robotics.

Roberto, Viola (2017). Robotics will be a Key Driver of Economic Growth, The Parliament Magazine.www.theparliamentmagazine.eu/articles/opinion/robotics-will-be-key-drivereconomic-growth.

Rodriguez, G., \& Weisbin, C. R. (2003). In Avital, B., \& Clement, V. (2016). Agricultural Robots for Field Operations : Concepts and Components. Journal homepage :www.elsevier.com/locate/ISSN/ 15375110. Published online $13^{\text {th }}$ July, 2016.

Schueller, J. K. (2006). In Avital, B., \&Clement, V. (2016). Agricultural Robots for Field Operations : Concepts and Components. Journal homepage :

www.elsevier.com/locate/ISSN/15375110. Published online $13^{\text {th }}$ July, 2016.

Shittu, A. (2018). Federal Government to Create National Artificial Intelligence Ecosystem. Available at www.pulse.ng [Accessed Dec. 13, 2018].

Somoto, I. (2018). Challenges of Artificial Intelligence in Nigeria. Available at www.techcrest.net. [Accessed Dec. 13, 2018].

Tervo, K. and Koivo, H. N. (2014). In Avital, B., \& Clement, V. (2016). Agricultural Robots for Field Operations: Concepts and Components. Journal homepage: 
www.elsevier.com/locate/ISSN/15375110. Published online $13^{\text {th }}$ July, 2016.

The Guardian, (M. Guardian, September 18, 2018).

The Nigeria Extractive Industry and Transparency Initiative (NEITI, 2016 report). In Nsude, I., \& Emeokoro, C. (2017). Solid Minerals and Economic Development in Digital Age; Germany: Labert Academic Publishing.

The Third World Resurgence. Robots and Industrialization in Developing Countries. No: 319/320, March/April, 2017, pp. 14 -17. (The third world Resurgence (2017). Available at https:// www.twn.my/title2/resurgence/2017/319-320/cover02.htm[accessed $12^{\text {th }}$ December, 2018]

Thorstein, V. (1857 - 1929). In Asemah, E. S., Nwammuo, A. N., \& Nkwam-Uwaoma, A. O. A. (2017). Theories and Models of Communication; Jos: MATKOL Press.

Tripicchio, R., Satler, M., Dabisias, G., Ruffaldi, E., \&Avizza, C. A. (2015), Krishna, K. R. (2016), Bambury (2015). In Kitonsa, H., \& Kruglikov, S. V. (2018). Significance of Drone Technology for achievement of the United Nations Sustainable Development Goals.www.r-economy.ru

United Nations Conference on Trade and Development (UNCTAD, 2017). Robots and Industrialization in Developing Countries.www.researchpublish.com.

\section{ABSTRACTS}

In this era of industrialization, a lot has been accomplished by robots particularly in developed countries to improve the nations' economies. The six major areas of robotics which are expected to make major economic impact and contribute to national development include : drones, artificial assistants, driverless cars, medical procedures, operations, prosthetics, and exoskeleton. Most robots increase productivity, improve workers' safety and make work more comfortable. Furthermore, robots help humans with odd jobs that are dangerous. It is expected therefore that deployment of robots can lead to economic growth and national development in Nigeria. This is a position paper that will enlighten Nigeria as a nation on the need for robots which will serve as a remedy for resuscitating her dwindling economy. The study was anchored on two theories namely : Technological Determinism and Social Construction of Technology Theories. The related literature was reviewed and the paper discussed and analysed succinctly. Appropriate communication strategies to create awareness among Nigerians were postulated. It is revealed that the benefits of robots outweigh the challenges thus the need for the deployment of robots in Nigeria. Four recommendations were made, one of which is that the government should establish Federal Agency for robots and robotics in Nigeria to create awareness, monitor and oversee the smooth running of deployment of robots.

En cette ère d'industrialisation, les robots ont permis des avancées dans l'amélioration des économies nationales, en particulier dans les pays développés, pour améliorer l'économie des nations. Les six principaux domaines de la robotique qui devraient avoir un impact économique majeur et contribuer au développement national sont les suivants : les drones, les assistants artificiels, les voitures sans conducteur, les procédures médicales, les opérations, les prothèses et les exosquelettes. La plupart des robots augmentent la productivité, améliorent la sécurité des travailleurs et rendent le travail plus confortable. En outre, les robots aident les humains à effectuer des petits travaux dangereux. On s'attend donc à ce que le déploiement de robots puisse conduire à la croissance économique et au développement national au Nigeria. Cette prise de position éclairera le Nigéria en tant que nation sur le besoin de robots comme remède à une économie en déclin. L'étude s'appuie sur deux théories, à savoir le déterminisme technologique 
et la construction sociale des théories technologiques. La littérature correspondante a été passée en revue et le document a été discuté et analysé de manière succincte. Des stratégies de communication appropriées pour sensibiliser les Nigérians ont été proposées. Il s'avère que les avantages des robots l'emportent sur les difficultés, d'où la nécessité de déployer des robots au Nigeria. Quatre recommandations ont été formulées, dont l'une est que le gouvernement devrait créer une agence fédérale pour les robots et la robotique au Nigeria afin de sensibiliser, de contrôler et de superviser le bon déroulement du déploiement des robots.

In dieser Ära der Industrialisierung haben Roboter vor allem in den entwickelten Ländern viel erreicht, um die Wirtschaft der Nationen zu verbessern. $\mathrm{Zu}$ den sechs Hauptbereichen der Robotik, die große wirtschaftliche Auswirkungen haben und zur nationalen Entwicklung beitragen dürften, gehören: Drohnen, künstliche Assistenten, fahrerlose Autos, medizinische Verfahren, Operationen, Prothesen und Exoskelett. Die meisten Roboter erhöhen die Produktivität, verbessern die Sicherheit der Arbeitnehmer und machen die Arbeit komfortabler. Darüber hinaus helfen Roboter Menschen bei Gelegenheitsarbeiten, die gefährlich sind. Es wird daher erwartet, dass der Einsatz von Robotern zu Wirtschaftswachstum und nationaler Entwicklung in Nigeria führen kann. Dies ist ein Positionspapier, das Nigeria als Nation über den Bedarf an Robotern aufklären wird, die als Heilmittel zur Wiederbelebung seiner schrumpfenden Wirtschaft dienen sollen. Die Studie basiert auf zwei Theorien, nämlich: Technologischer Determinismus und soziale Konstruktion von Technologietheorien. Die diesbezügliche Literatur wurde gesichtet und das Papier kurz und bündig diskutiert und analysiert. Geeignete Kommunikationsstrategien zur Bewusstseinsbildung unter den Nigerianern wurden postuliert. Es zeigt sich, dass die Vorteile von Robotern die Herausforderungen überwiegen und somit die Notwendigkeit des Einsatzes von Robotern in Nigeria. Es wurden vier Empfehlungen ausgesprochen, von denen eine lautet, dass die Regierung eine Bundesagentur für Roboter und Robotik in Nigeria einrichten sollte, um das Bewusstsein für den Einsatz von Robotern zu schärfen und den reibungslosen Ablauf zu überwachen und zu kontrollieren.

\section{INDEX}

Schlüsselwörter: Kommunikation, Roboter, Robotik, sich entwickelnde Wirtschaft, nationale Entwicklung

Mots-clés: Communication, Robots, Robotique, Economie en développement, Développement national

Keywords: Communicating, Robots, Robotics, Developing Economy, National Development

\section{AUTHOR}

\section{IFEYINWA NSUDE}

Department of mass communication

Ebonyi state university

Abakaliki, Nigeria

Email: ifeyinwansude@gmail.com 